\title{
THE USE OF INFORMATION MANAGEMENT AS A DECISION MAKING TOOLS OF PROPHET SULAIMAN
}

\author{
Anang Kunaefi M.Kom ${ }^{1)}$, Nita Yalina, S.Kom, M.MT ${ }^{2)}$ \\ State Islamic University of Sunan Ampel Surabaya \\ 1'akunaefi@uinsby.ac.id, ${ }^{2}$ nitayalina@uinsby.ac.id
}

\begin{abstract}
In the information era today, value of data and Information is increasing rapidly. Data and information become more and more important to organization, because it is used as a tools in making decisions. A lot of concept and theory about data and information management has been launched. Our research tried to study and make a bridge between today's theory about information management and Islamic values based on Islamic history written in Alquran. We took Prophet Sulaiman as our case. Sulaiman was a Prophet as well as a King. He was awarded intelligence and wisdom of God. We learn the story of Sulaiman and performed a literature review and cross references to various theories of information management. We found that Prophet Sulaiman uses data and process it into valuable information, to make right decision. We believe that, during his age, Prophet Sulaiman had implement basics of information management concept and theory.
\end{abstract}

Keywords: data, information, information management, Sulaiman, science and Islam

\section{INTRODUCTION}

Since the time of the Prophet Muhammad, there is no separation between science and Islam. Problems of the society including health, politics, social, cultural and many other fields refers to the science of religion. But as the time passed, coupled with the influx of western science, there were big dichotomy between Islam and science. This encourages the emergence of technology that is completely separated with religion. In the last few years, many scholars began the idea of integration between science and Islam. It happens as a form of awareness that the dichotomy could create bad impact of science. Previously, some researchers have done the integration and create several models of integration. The models are ranging from the level of concept to implementation.

Huzni Thoyyar (t.t) and Mohamad Solikin [1] states that there are several factors that trigger the integration of knowledge particularly Islamic Studies. Firstly, factor of history of science and religion. Secondly, the strong pressure from scholars who oppose the freedom of science. Thirdly, crisis occurs of science and technology. Fourth, Muslims are fall behind in terms of science and technology.

Today is The Information Age (also known as the Computer Age, Digital Age, or New Media Age). The Information Age is a period in human history characterized by the shift from traditional industry that the Industrial Revolution brought through industrialization, to an economy based on information computerization. The emergence of the Information Age is associated with the Digital Revolution, just as the Industrial Revolution marked the emergence of the Industrial Age [2]. On this information era, the value of data is increasing rapidly. Variety of information can be generated from the data. It depends on how it is contextualized, categorized, calculated and condensed. Therefore, data management became more important today.

Based on authors' findings, the management of data and information was already done since thousands of years ago even before the concept of the data and information itself was founded and written. This paper tried to revisit how data and information management is done thousands of years ago, precisely at the time of Prophet Sulaiman AS. This paper tried to aligning the concept of data and information that is currently applied, and the management of data that have been done by Prophet Sulaiman AS.

This concept then reviewed, cross referenced and then reunited with the authentic source of Muslims, i.e. Al-Quran and Hadith. This paper tried to harmonize the concept of data and information with the story of the Prophet Sulaiman explicitly mentioned in the Qur'an.

This paper is expected to give an idea of coherence between science, especially in the field of Information Technology (IT), with the science of religion based on the Qur'an and Hadith. This paper is expected to explain how the concept of data and 
information management applied by the Prophet Sulaiman centuries ago.

\section{INFORMATION THEORY}

\subsection{Data, Information and Knowledge}

Nowadays, data and information is very important for organization. It is because the data and information is the raw material of a knowledge base that will become a foothold in the decision. Data represent real-world things. According to Thierauf [3], data can be defined as unstructured facts and figures that have the least impact on the typical organization. Data can also be defined as a description of an event that we face [4].

Information, on the other hand, is collections of facts organized and processed according to specific context so that they have additional value [5]. Table 1 below describe the difference between data and information.

Table 1. Data vs. Information

\begin{tabular}{|l|l|l|}
\hline Definition & \multicolumn{1}{|c|}{ DATA } & \multicolumn{1}{|c|}{$\begin{array}{l}\text { INFORMATION } \\
\text { and figures }\end{array}$} \\
\hline Form & $\begin{array}{l}\text { Numbers, letters, } \\
\text { characters, pictures, } \\
\text { etc. }\end{array}$ & $\begin{array}{l}\text { Result of a process } \\
\text { and have additional } \\
\text { value }\end{array}$ \\
$\begin{array}{l}\text { Summary, } \\
\text { conclusion } \\
\text { statement, diagram, } \\
\text { etc. }\end{array}$ \\
\hline
\end{tabular}

Transformation process is needed in order to turn data into useful information. Transformation process includes various activities like selecting, organizing, contextualizing, categorizing, manipulating and calculating the data [6].

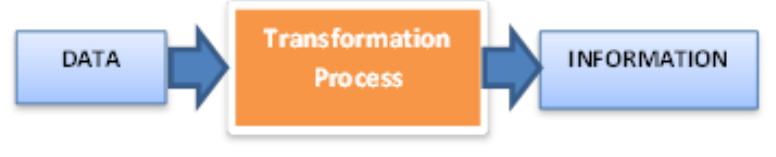

Figure 1. Transformation Process

Knowledge is closely linked to doing and implies know-how and understanding. The knowledge possessed by each individual is a product of his experience, and encompasses the norms by which he evaluates new inputs from his surroundings [6]. Gamble and Blackwell [7] define Knowledge as a fluid mix of framed experience, values, contextual information, expert insight, and grounded intuition that provides an environment and framework for evaluating and incorporating new experiences and information. It originates and is applied in the mind of the knowers. In organizations it often becomes embedded not only in documents or repositories, but also in organizational routines, practices and norms.

Understanding is an interpolative and probabilistic process. It is cognitive and analytical. It is the process by which soemone can take knowledge and synthesize new knowledge from the previously held knowledge. The difference between understanding and knowledge is the difference between "learning" and "memorizing". Understanding can build upon currently held information, knowledge and understanding itself [8].

Wisdom is an extrapolative and nondeterministic, non-probabilistic process. It calls upon all the previous levels of consciousness, and specifically upon special types of human programming (moral, ethical codes, etc.). Wisdom is therefore, the process by which we also discern, or judge, between right and wrong, good and bad [8].

By gaining wisdom, the action or decision could be made. A good knowledge will lead to good decisions, and vice versa. Figure 2 shows the hierarchy of data, information, knowledge and wisdom.

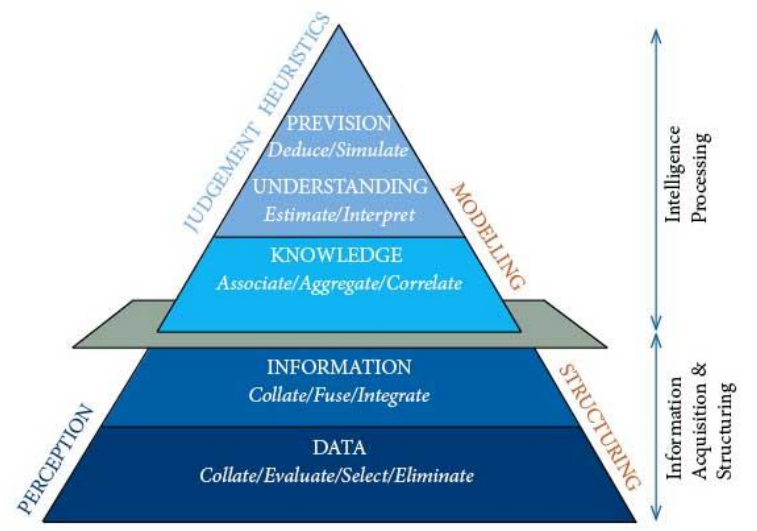

Figure 2: Data, Information, Knowledge, Wisdom

(Adapted from Ackoff \& Russell,1989)

\subsection{Information Quality}

The value of information depends on its quality. John Burch and Gary Grudnitski [9] describe the quality of the information by the shape of the building consists of three pillars, that is accurate, relevant and timely.

Accurate means that information should be free from mistakes and not biased or misleading. In the process to the recipient, information may got a lot of interference that can alter or destroy the information [10]. Therefore, information must clearly reflect the intent.

Times means that information may not be received late. Information that is outdated will have no value anymore. Information is the cornerstone in 
making decisions, if the decision making process too late, it can be fatal [10].

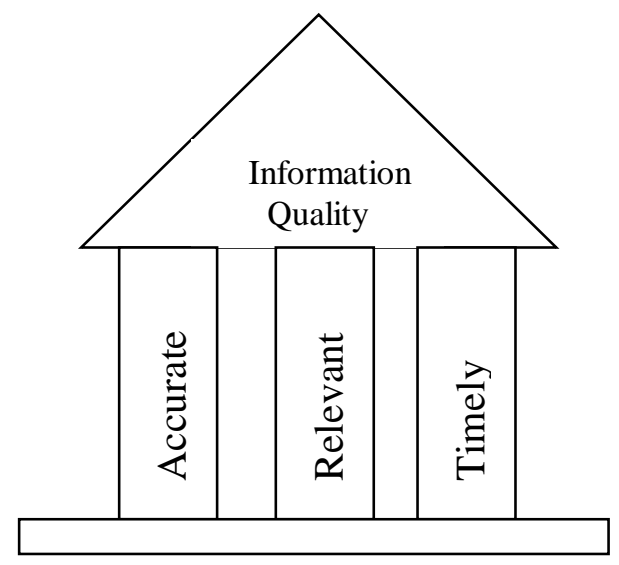

Figure 3: Pillars of Information Quality

Relevant means information should have the advantage for the user. Relevant information may be different for each user [10].

Information Cycle

As mentioned earlier, data must be processed first in order to become information. Information obtained will then become a basic knowledge in performing an action or decision. Therefore, data and information has a cycle as illustrated in figure 3 .

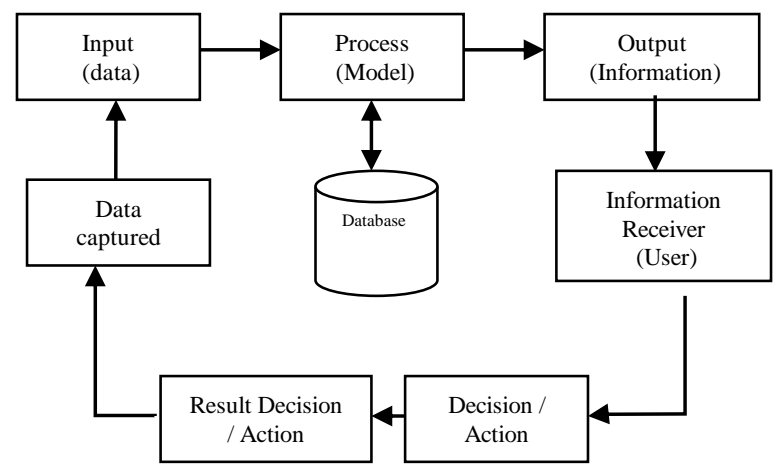

Figure 4: Information Cycle

As can be seen above. First, the data is captured by human senses. Then the data is processed to produce information. Information obtained by the recipient will be used as the basis of knowledge in taking actions or decisions.

\subsection{Security of Information and Data}

Information security is a branch of study specializing in information technology to learn methods and techniques to protect information from unauthorized access, use, dissemination, destruction, alteration, and destruction without legal authorization. The most well-known model about information security is The CIA Triad. The CIA Triad is a model for security policy development, used to identify problem areas and necessary solutions for information security.

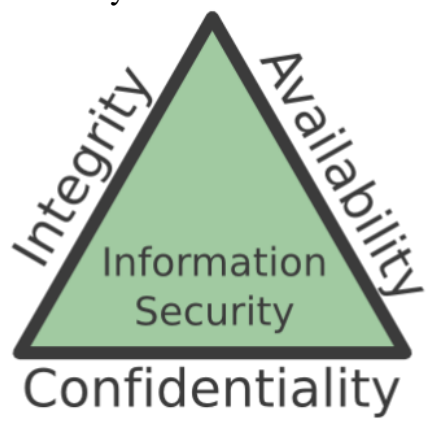

Figure 5: The CIA Triad

Integrity of information refers to protecting information from being modified by unauthorized parties. Availability of information refers to ensuring that authorized parties are able to access the information when needed. Confidentiality refers to protecting the information from disclosure to unauthorized parties [11].

\subsection{Characteristic of Valuable Information}

The value of the information is based on the characteristic of the information itself. Based on Stair [5], there are 11 characteristic of valuable information, includes Accessible, Accurate, Complete, Economical, Flexible, Relevant, Reliable, Secure, Simple, Timely, and Verifiable.

Table 2. Characteristics of Information (Stair, 2012)

\begin{tabular}{|c|c|}
\hline Term & Definition \\
\hline Accessible & $\begin{array}{l}\text { Information could be accessed whenever it } \\
\text { is needed }\end{array}$ \\
\hline Accurate & $\begin{array}{l}\text { Information should be free from any } \\
\text { mistakes }\end{array}$ \\
\hline Complete & $\begin{array}{l}\text { information should be contains all the things } \\
\text { that the user need to be known }\end{array}$ \\
\hline Economical & $\begin{array}{l}\text { information should be produced } \\
\text { economically }\end{array}$ \\
\hline Flexible & $\begin{array}{l}\text { information can be used to variety of } \\
\text { purpose }\end{array}$ \\
\hline Relevant & $\begin{array}{l}\text { information should be important and } \\
\text { appropriate to the user }\end{array}$ \\
\hline Reliable & $\begin{array}{l}\text { the source of the information could be } \\
\text { trusted }\end{array}$ \\
\hline Secure & $\begin{array}{l}\text { information has met the security aspect of } \\
\text { information as explained before }\end{array}$ \\
\hline Simple & $\begin{array}{l}\text { information does not contain the data that is } \\
\text { not needed }\end{array}$ \\
\hline Timely & information arrive in time \\
\hline Verifiable & the information could be checked \\
\hline
\end{tabular}




\section{PROPHET SULAIMAN}

Prophet Sulaiman was a prophet and a king at once. He has an army consisting of jinn, humans and animals. This is what Allah says in Surah AnNaml: 17.

ليُوزَعُونَ

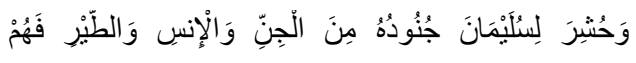

Which means, "and before Sulaiman were marshalled His hosts,- of Jinns and men and birds, and They were all kept In order and ranks".

Prophet Sulaiman had a huge empire. The Greatness of Sulaiman drawn from his prayer that is granted by God in Surah Shad: 35 .

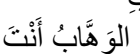

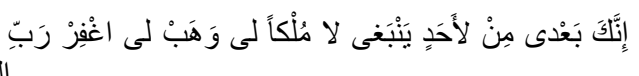

He said, "O My Lord! forgive me, and grant me a kingdom which, (it may be), suits not another after Me: for Thou art the Grantor of bounties (without measure).

The greatness of Prophet Sulaiman as a king also describes in Surah Saba verses 12 to 13, where Allah said that the wind and the jinn were conquered and worked for Sulaiman with the permission of Allah. And, when Sulaiman traveling from morning till noon, he will passes a distance equal to the distance the camel ride fast in a month.

From those verses of Al-Qur'an, we can conclude that Prophet Sulaiman has been given a great blessing from God.

\section{INFORMATION MANAGEMENT OF PROPHET SULAIMAN}

\subsection{Bird of Hudhud}

Ibn Kathir narrates in his book that Hudhud is a bird expert in search of water. $\mathrm{He}$ was commissioned specifically by Prophet Sulaiman to find the source of water in the Sahara desert. With its ability, it can see the water in the soil. And he can tell how far away the depth of water springs from the ground.

One day the Prophet Sulaiman gathered with his soldiers, and did not see Hudhud. So he said he would punish Hudhud unless it brings obvious reasons. It is narrated in Surah An-Naml: 21.

Not long after, Hudhud came and brought important news. There are 4 data items provided by Hudhud to Sulaiman, as illustrated in the following table:

Table 3. Facts From Hudhud

\begin{tabular}{|c|c|}
\hline 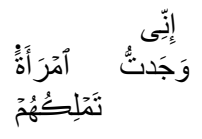 & $\begin{array}{l}\text { I found a woman ruling } \\
\text { over them }\end{array}$ \\
\hline 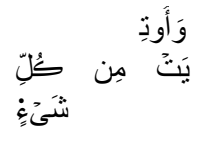 & $\begin{array}{l}\text { she has been given all } \\
\text { things that could be possessed by } \\
\text { any ruler of the earth }\end{array}$ \\
\hline وَلَهَها & she has a great throne \\
\hline 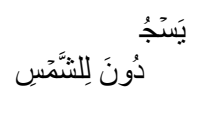 & $\begin{array}{l}\text { I found her and her } \\
\text { people worshipping the sun } \\
\text { besides Allah }\end{array}$ \\
\hline
\end{tabular}

From the table above, it can be seen that facts delivered by Bird Hudhud has met the standard of data, that the facts are taken based on direct observation.

Data supplied by Hudhud was not immediately accepted by Sulaiman, it is proved by his words in verse 27 , "Will we see, what you really, or are you among those who lie".

It is an evidence that Sulaiman wants to validate whether the data is valid or not. The next verse gives a clue that Sulaiman send a letter to the woman ruled the empire (Balqis).

\subsection{Queen Balqis and Her Throne}

Sheba is a wealthy empire and has a huge army. Narrated by Ibn Kathir in his book, that the Empire of Sheba forces numbered more than a hundred thousand people. This country is led by a Queen named Balqis.

Queen Balqis has a magnificent throne. The throne has a length of eighty feet and its width fourty feet. Along the throne decorated with gold and various gemstones and pearls. The throne is set in an enormous palace, tall and sturdy.

Following the instruction of the Prophet Sulaiman, Hudhud bring the letter using his beak. Arriving at the palace of the Queen Balqis, he went to a quiet place in the place where the Queen used to be alone. Hudhud then tossed the letter right in front of the Queen Balqis. After that, Hudhud move backward as ethical attitudes as well as to wait to know the reaction of the Queen.

Queen Balqis who saw it were amazed, that she never seen anything like this before. So she said, "has come to me a noble letter" (An Naml: 29).

After the letter received by Balqis, she went to gather the scholars in her empire and opened the letter. Surah An-Naml:30 states the content of the 
letter, which means "It is from Sulaiman, and is (as follows): In the name of Allah, Most Gracious, Most Merciful. Be not arrogant against me, but come to me In submission (to the true Religion)."

The first message in the letter, contains introduction to the existence of God. It is none other because Sulaiman has earned the previous information from Hudhud that Balqis and her Kingdom worship the sun.

Second message in the letter that ask Queen Balqis to not arrogant, shows that Sulaiman knows that the kingdom of Sheba blessed with wealth and prosperity. Then, it ends with an invitation to make submission to Islam. It also became evident that Sulaiman has made the previous information (that Kingdom of Sheba worshiped the sun) as a basis for Sulaiman to write the message. Therefore, this verse was a proof that the data submitted by the Hudhud is valid.

\subsection{The Greatness of Prophet Sulaiman}

The greatness of Sulaiman can be seen when the Queen Balqis finally came together with tens of thousands of her troops into the kingdom of Sulaiman to fulfill his invitation.

Queen Balqis is a clever leader. Earlier, the Queen Balqis has sent thousands envoy to give gifts to the Prophet Sulaiman. Narrated by Ibn Kathir that Queen Balqis send a gift in a very large amount of gold, gems, pearls and more. She said, "If Sulaiman accept it, meaning he is a king, you must fight him. And if he rejects it, meaning he is a prophet, then follow him".

History has recorded that the Prophet Sulaiman did not see any of the gifts, and reject it. So they went home in a state of abject and defeated.

Before leaving her kingdom, Queen Balqis ordered her army, that her throne that was made of gold and jewels, stored in the deepest part of the seven layer rooms. Each layer had a door and it's locked. Then she said, "Take care of this throne with all the power that you have". Afterward, Queen Balqis departed together with twelve thousands convoy of troops to the kingdom of Prophet Sulaiman.

Prophet Sulaiman continues to monitor the journey of Queen Balqis, and assigning jinn to report to him every day and night. It is a proof that Prophet Sulaiman has implemented the characteristic of information, that is Accessible, or information could be accessed whenever it is needed.

When the convoy of Queen Balqis was close, Sulaiman gathered his men and said, "which of you can bring me Her Throne before They come to me In submission?" (An-Naml: 38). Then jinn answered, "I will bring it to Thee before Thou rise from Thy council". Sulaiman said, "I want a faster than that!"

Someone one who had knowledge of the Book said: "I will bring it to Thee within the twinkling of an eye!" then when (Sulaiman) saw it placed firmly before him, He said: "This is by the Grace of My Lord!- to test me whether I am grateful or ungrateful!"” (An-Naml:40).

Ibn Kathir said, Prophet Sulaiman wanted more quickly because he did not want to be late. If the Queen Balqis arrived first, and converted to Islam, it is forbidden for Sulaiman to take her throne. It is once again a proof that Prophet Sulaiman has implemented the characteristic of information, that is timely or realtime.

\subsection{Decision Making Process}

From the previous explanation, it appears that Prophet Sulaiman always use the information as a basis for making the decisions. Table 4 below shows the decisions taken by Sulaiman and any information that serve as its foundation.

Table 4. Decision Making Process

\begin{tabular}{|c|c|c|}
\hline o. & $\begin{array}{l}\text { Sulaiman's } \\
\text { Decision }\end{array}$ & $\begin{array}{l}\text { Information } \\
\text { Referred }\end{array}$ \\
\hline & \begin{tabular}{llll} 
& \multicolumn{3}{c}{ Introducing } \\
Allah & as & a & God \\
(letter) & & & \\
\end{tabular} & $\begin{array}{l}\text { Kingdom of } \\
\begin{array}{l}\text { Sheba } \\
\text { worshipping } \\
\text { the sun }\end{array}\end{array}$ \\
\hline & $\begin{array}{l}\text { Ask Queen } \\
\text { Balqis not to be } \\
\text { arrogant and make } \\
\text { submission to Islam } \\
\text { (letter) }\end{array}$ & $\begin{array}{l}\text { Kingdom of } \\
\text { Sheba is a wealthy } \\
\text { kingdom, } \\
\text { worshipping the sun }\end{array}$ \\
\hline & $\begin{array}{l}\text { Refusing to } \\
\text { Queen Balqis's grant } \\
\text { and built an } \\
\text { outstanding palace } \\
\text { made of glass }\end{array}$ & $\begin{array}{l}\text { Kingdom of } \\
\text { Sheba is a wealthy } \\
\text { kingdom }\end{array}$ \\
\hline & $\begin{array}{l}\text { Ordered jinn } \\
\text { to monitor the } \\
\text { journey of Queen } \\
\text { Balqis }\end{array}$ & \begin{tabular}{lr}
\multicolumn{2}{c}{ From } \\
previous & event \\
Sulaiman & rejects \\
Queen Balqis grant
\end{tabular} \\
\hline & $\begin{array}{l}\text { Ordered his } \\
\text { men to move Queen } \\
\text { Balqis' throne before } \\
\text { her arrival }\end{array}$ & $\begin{array}{l}\text { Queen } \\
\text { Balqis have a great } \\
\text { throne, and report } \\
\text { from jinn that she was } \\
\text { already close }\end{array}$ \\
\hline
\end{tabular}

In addition, what is seen by Hudhud when it was first arrived at Sheba is very likely varied and numerous. Mainly related to worship and fraud committed by residents of Sheba. However, Hudhud conclude with just one information that they worshiped the sun and Satan has deceived them. Therefore we can conclude 
here that the Hudhud have made the process of transforming data into information by conducting summary and contextualization.

We can also find that, by sending Hudhud to bring his letter directly to Queen Balqis, Sulaiman also implement the CIA triad to protect the information that he wants to send. Hudhud wants to protect the letter so that it gave the letter to Queen Balqis by itself. It is a proof that Prophet Sulaiman try to preserve the integrity, confidentiality and availability of the letter that he was sent.

This finding raises interesting fact that Sulaiman, in his day, has use management of information as a basis in his decisions. This also shows and confirming information from many Islamic sources, that says Sulaiman endowed with knowledge and wisdom from God.

\section{CONCLUSION}

In the information era todays, data and information is crucial to organization. This is because all actions or decisions can only be done when the organization has been informed by data which is accurate, relevant and timely. Therefore, the management of data and information is a necessity to organization.

The wise decisions and actions that have been made by Prophet Sulaiman were inseparable from the concept of a good practice of data and information management.

Table 5. Conclusion

\begin{tabular}{|c|c|c|}
\hline Characteristics & Implementation & Compliance \\
\hline Information Cycle & $\begin{array}{l}\text { Prophet Sulaiman has followed a cycle of information theory. In } \\
\text { every action and decision-making which has been done is based on } \\
\text { data and information that he obtained earlier from bird Hudhud }\end{array}$ & $\checkmark$ \\
\hline Accurate & $\begin{array}{l}\text { Prophet Sulaiman did not directly trust the data which was provided } \\
\text { by Hudhud, he validated the data which was provided by Hudhud to } \\
\text { ensure that the data was accurate. }\end{array}$ & $\checkmark$ \\
\hline Timely & $\begin{array}{l}\text { Information which is given by Hudhud is timely because it happened } \\
\text { when the Prophet Sulaiman became king and has enormous power at } \\
\text { the time. }\end{array}$ & $\checkmark$ \\
\hline Relevant & $\begin{array}{l}\text { Information delivered by Hudhud about Kingdom who worshiped } \\
\text { the sun is very relevant to the prophetic duty of Sulaiman }\end{array}$ & $\checkmark$ \\
\hline Secure & $\begin{array}{l}\text { Letter sent by Hudhud was given directly to the Queen Balqis to } \\
\text { keep the information secure }\end{array}$ & $\checkmark$ \\
\hline Verifiable & $\begin{array}{l}\text { Prophet Sulaiman sent a letter to the Queen Balqis as a method to } \\
\text { check and verify that the information he received from Hudhud was } \\
\text { accurate. }\end{array}$ & $\checkmark$ \\
\hline Complete & $\begin{array}{l}\text { Information provided by the Hudhud was complete; the main } \\
\text { information is about the people worshiping the sun. In addition, } \\
\text { about wealth and throne of the Queen Balqis }\end{array}$ & $\checkmark$ \\
\hline Simple & Information provided by the Hudhud is short, clear and useful. & \\
\hline Economical & Not Defined & $x$ \\
\hline Flexible & $\begin{array}{l}\text { Information about wealth of the Sheba Kingdom and the Throne of } \\
\text { the Queen Balqis were not seem relevant at the beginning, but } \\
\text { turned out to be the basis for various decision of Sulaiman to made } \\
\text { Queen Balqis stunned later. }\end{array}$ & $\checkmark$ \\
\hline Reliable & Not Define & $x$ \\
\hline Accessible & $\begin{array}{l}\text { Ordered jinn to monitor the journey of Queen Balqis and report to } \\
\text { Sulaiman every day and night }\end{array}$ & $\checkmark$ \\
\hline
\end{tabular}


The Story of Prophet Sulaiman describe in the Qur'an clearly prove that since thousands of years ago, the concept of the data and the information is already used and practiced by Prophet Sulaiman. Prophet Sulaiman is known by the people as a wise and smart king. This is reflected in every action and decision taken by the Prophet Sulaiman has been described clearly in the previous section.

We made three-column table as a conclusions. The first column represent characteristics of information according to today's information theory and concept. The second column represent decisions taken by Prophet Sulaiman. The third column represent compliance of both. The details can be seen in Table 5 .

From these findings, we can conclude that Prophet Sulaiman implement almost all aspects from the concept of data and information management which were describe before.

\section{REFERENCES}

[1] Huzni Thoyyar (t.t). Model-model integrasi ilmu dan upaya membangun landasan keilmuan Islam telah diambil dar ihttp://www.ditpertais.net/annualconferen ceancon06/Makalah\%20-

Husni\%20Thoyyar.pdf, 13 April 2012.

[2] Hilbert, M. (2015). Digital Technology and Social Change [Open Online Course at the University of California] (freely available). Retrieved from https://canvas.instructure.com/courses/949415

[3] Thierauf, R. J. (1999). Knowledge Management Systems for Business. Westport Conn, Quorum Books. Knowledge Management Tools Articles: Angell, I. (1998).

[4] Al-Bahra bin Ladjamudin. 2005. Analisis dan Desain Sistem Informasi. Yogyakarta : Graha Ilmu.

[5] Stair, Ralph; Reynolds, George (2012), Fundamentals of Information System Sixth Edition, Cengage Learning.

[6] Davenport, T. H. \& Prusak, L. (2000). Working knowledge: How organizations manage what they know. Boston, MA: Harvard Business School Press.

[7] Gamble, P.R., \& Blackwell, J. (2001), Knowledge Management: A State of the Art Guide, Kogan Page Ltd.
[8] Ackoff \& Russell (1989). "From Data to Wisdom". Journal of Applied Systems Analysis 16: 3-9.

[9] Burch, John dan Grudnitski, Gary. 1986. Information Systems Theory and Practice. New York: John Wiley \& Sons

[10] Jogiyanto, Hartono.(2005). Analisis \& Desain Sistem Informasi Pendekatan. Terstruktur Teori dan Praktek Aplikasi Bisnis. Andi Yogyakarta.

[11] Perrin, Chad. "The CIA Triad". http://www.techrepublic.com/blog/itsecurity/the-cia-triad/ Retrieved 12 August 2016 
